\title{
LOCRI EPIZEPHYRII AND THE LUDOVISI THRONE
}

\section{[Plate XI.]}

THE starting-point for the following discussion is the stele from the Esquiline ${ }^{1}$ (Plate XI.). We remark first its stylistic relationship with a series of terracottas from Locri Epizephyrii, many of which have been published by Quagliati in Ausonia, iii. 1908, p. 136 sqq. and by Orsi in Bollettino d'Arte, iii. 1909, p. 406 sqq. and p. 463 sqq., while there are other examples in various museums. For style, we may compare particularly Aus. l.c. Figs. 9, 33, 44; Boll. l.c. Fig. 16, and Fig. 1 (=B.M. Terracottas, B488, Pl. XXI.) : for subject Aus. l.c. Fig. 1. If this connexion can be established, the consequences are of importance, for the stele from the Esquiline has often been compared in style with the Ludovisi Throne, and the Ludovisi Throne involves the Boston reliefs. Before examining this comparison we must mention yet another work which has been brought into relation with these monuments, the so-called Ino-Leucothea relief of the Villa Albani. ${ }^{2}$ Its connexion with the Esquiline stele and with some of the terra-cottas is, in fact, equally striking. With the stele it has in common, in the seated figure the emphatically linear treatment of the himation, that is to say, a tendency to draw rather than to model; and the identical device for rendering the softer material in the standing figure (a device also used in the terra-cottas, ${ }^{3}$ while the line of the front of the thigh is indicated through the drapery in the same way. In short, it is fair to say that if a reduced copy of the Albani relief had been unearthed among such terra-cottas as Aus. l.c. Figs. 4, 15, 44, 45, 46, 58, and Boll. l.c. Fig. 43, to mention only a few examples, we should not notice any incongruity of style, and the subject in some cases is curiously similar. ${ }^{4}$

Turning now to the Ludovisi Throne, we find that it appears to be later than most, if not all, of the terra-cottas, and probably later than the stele and the Albani relief; but there is no serious divergence of style, the headshape is notably the same,${ }^{5}$ and in all, to note a single important resemblance,

1 Conservatori Catalogue, Monumenti Arcaici, No. 5. Greyish island marble. Restored (in plaster) : patches on edge of moulding, and a thin horizontal strip under right arm of figure where relief has been broken in two.

2 Helbig $^{3} 1863$.

3 Aus. 1.c. Fig. 83. Here possibly imitated from metal technique like the granulated treatment in certain other of the terra-cottas ('Aus. 1.c. Fig. 74, etc.).
Compare the silver rhyton from Tarentum at Trieste (Jahresh. v. 1902, p. 112). That Locri abounded in metal treasures we know both from the terra-cottas and from literary evidence.

4 The resemblance between the Iudovisi Throne and the terra-cottas has been noted both by Amelung (Helbig ${ }^{3}$ 1286) and by Ducati ( $L$ 'Arte Classica, p. 293).

5 Aus. l.c. Figs. 44, 54, 55. 


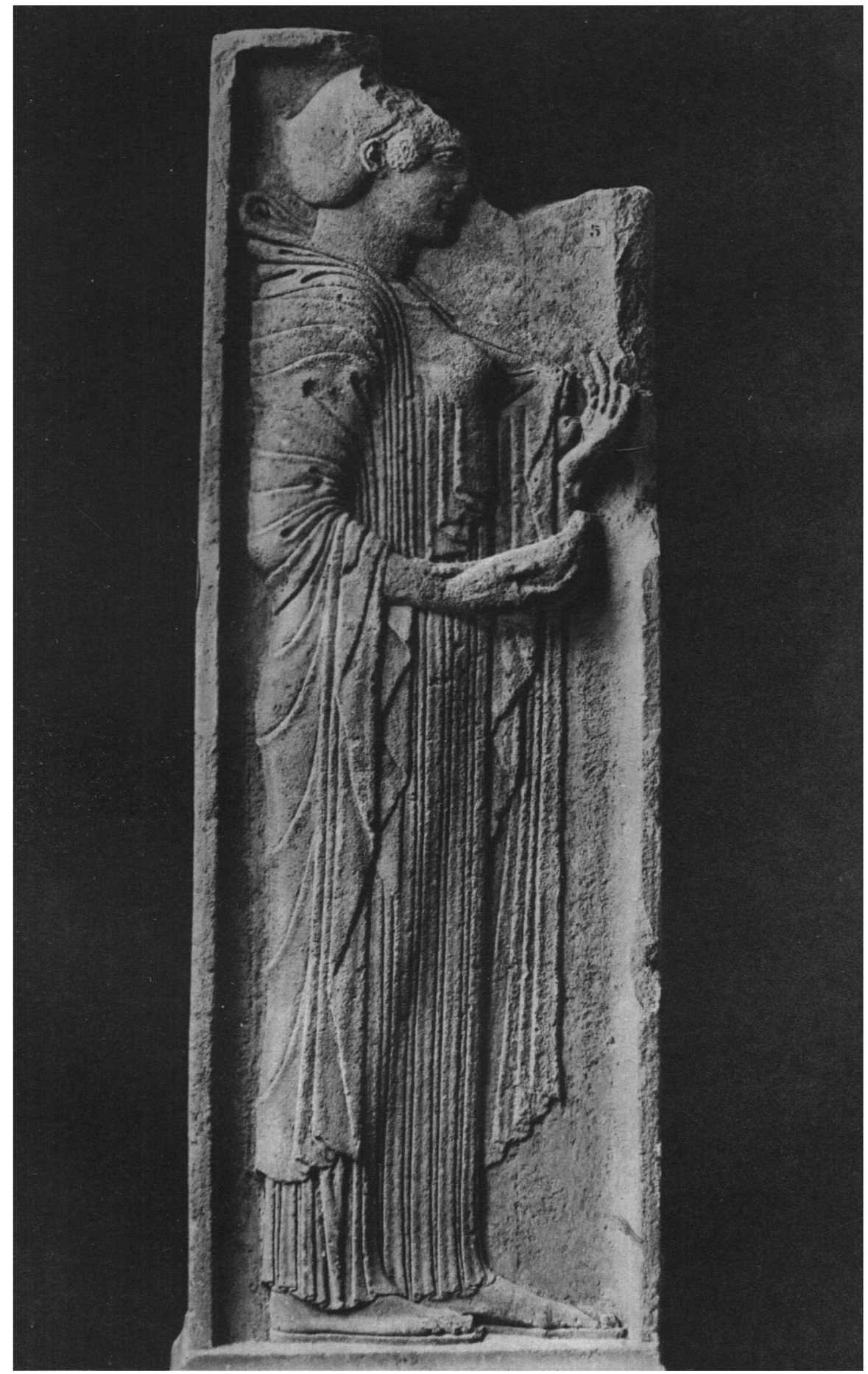

MARBLE RELIEF FROM THE ESQUILINE 
the female chest is unusually firm and prominent. Further, one of the few pieces of sculpture found at Locri itself, the west pedimental group or acroteria, ${ }^{6}$ shows in the drapery of the Tritons a flattening of the surfaces and a rounding of the edges of the folds which comes close to the drapery treatment of the attendants in the main scene of the Ludovisi Throne; while the male form is not distant from that of the Boston reliefs. On stylistic grounds, then, we might suppose some connexion between all these monuments and Locri. Nor is it irrelevant, when we remember that the one influence admittedly apparent in them is the Ionic, that the temple at Locri, alone among those in South Italy, was of the Ionic order; and that the material employed is island marble, though not in all cases of identical grain and quality. ${ }^{7}$

But in subject the Ludovisi Throne furnishes us with a still more important point of contact. The main front scene has for one of its leading motives a sacred cloth or garment. In the Locrian terracottas, at least four sets show scenes of ritual concerned also with some kind of sacred garment. In the first it is being carried unfolded by four maidens accompanied by an older woman ${ }^{8}$; and we may notice the fact, perhaps not unconnected with the toilet scene, and with the dedication of mirrors in some sanctuary, ${ }^{9}$ that in one example these maidens, preceded by the woman, wear their hair loose, in another, where they are followed by her, it is confined, ${ }^{10}$ and, more important

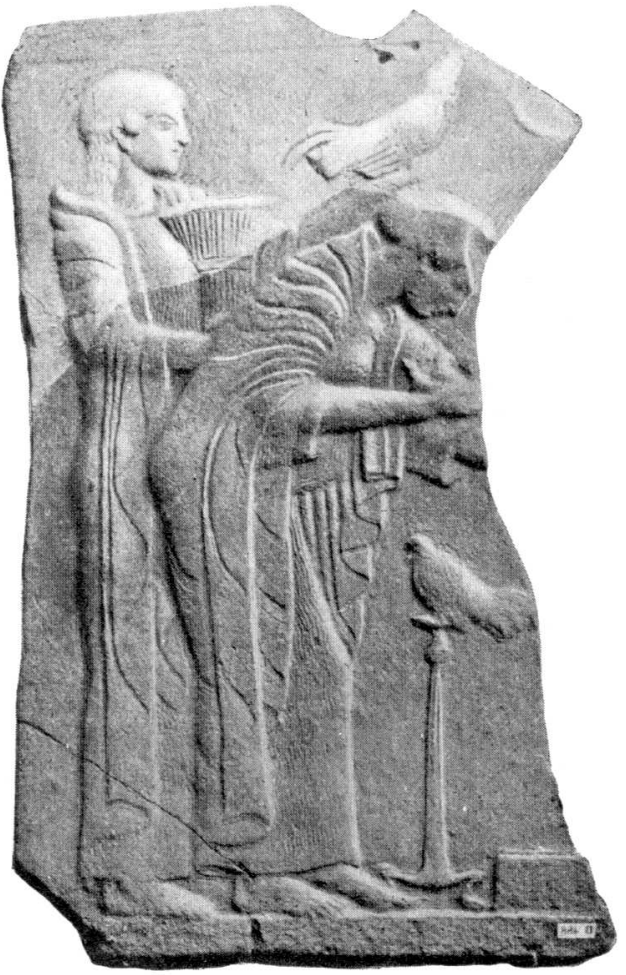

Fig. 1.-Terra-cotta Relief from Lochi. (British Museum). still, in Boll. l.c. Figs. 25 and 26 , there is between the two pairs of maidens a difference of drapery corresponding to (though not identical with) that in the attendants of the rising goddess on the Ludovisi Throne. In the second set the

- Ant. Denkm. v. 1890, Pll. LI. and LII. Röm. Mitt. v. 1890, pp. 161-227, P1. IX. These articles deal also with other remains at Locri. Now at Naples (Guida, No. 125, p. 39).

7 I am aware that, speaking broadly, all these monuments can be classed simply as Ionian. But that classification does not seem to account for all their peculiarities, though the style of the Albani relief is, I feel, not quite so characteristically South Italian as that of the Esquiline stele and the two thrones.

${ }^{8}$ Boll. 1.c. Figs. 25, 26; Aus. 1.c. Fig. 50 .

E.g. Aus. l.c. Fig. 57 ; Boll. l.c. Fig. 16.

10 See in this connexion Revue Hist. Relig. 80, (1919), xiv. p. 30. 
folded garment is seen carried by a maiden with or without an older woman. ${ }^{11}$ In the third, again folded, it lies on a table in front of some goddess. ${ }^{12}$ In yet another it is being placed in a chest; ${ }^{13}$ while finally it is seen held in front of what appears to be an already draped girl.14 Naturally one thinks at once of the Arrephoric maidens of the Parthenos, of the Despoina at Lykosura, and, amongst many others, of the Hera of Tiryns in the terra-cottas at Nauplia. ${ }^{15}$ The robing scenes in other examples must also be connected with this aspect of the ritual. ${ }^{16}$

As for the connexion of subject with the Boston reliefs, the most obvious link is that provided by the appearance of the pomegranate, which to us, as to both Greeks and Romans, is almost invariably the symbol of the underworld; so that, whether we connect the Boston relief with Locri or not, we must connect it with some under-world cult. At Locri itself, on the entablature of a shrine at some distance from that mentioned below, single pomegranates are carved in the round midway between the groups of guttae.

As far as the fishes are concerned, they appear frequently on the coins of South Italy and of Sicily, seldom on those of Greece proper. The whole scene of the Boston Throne I would bring into relation with the somewhat baroque west pediment or acroteria from Locri. The present symmetrical restoration is conjectural, but in any case the largest fragment represents a youth (usually believed to be one of the Dioscuri) leaping from a horse borne by a Triton. When we remember that the Dioscuri were, according to some legends, translated to heaven as morning and evening star, it surely follows that this part of the scene directly corresponds to the scenes of simple astronomical symbolism in the Parthenon pediment, on the basis of the Parthenos, and elsewhere, and shows one of the Dioscuri, who, at the hour of his setting, leaves the horse on which he has ridden the sky to plunge into the sea. ${ }^{17}$ Similarly the boys in the scales of the Boston relief, recalling in form the young stars of the Blacas vase, may be morning and evening star, or some stars whose respective appearance and disappearance, like the evening rising of Arcturus, was the sign for the beginning of certain agricultural operations and of the corresponding religious rites. ${ }^{18}$ There could be no simpler or more satisfying way of indicating the interdependent movement of the two stars than the exact, inevitable movement of a balance. One star rises from behind the land-horizon (the under-world, indicated by the

11 Boll. 1.c. Fig. 17; Aus. I.c. Fig. 53.

12 Boll. 1.c. Fig. 6; Aus. l.c. Figs. 47, 48.

13 Aus. l.c. Fig. 63.

14 Aus. l.c. Figs. 60, 61 and 62. Her companion on the placque has the left breast bare. That is to say we are looking at a religious ceremony of robing and disrobing, analogous to, if not identical with that suggested by the three subjects of the Ludovisi Throne.

15 Casson's theory (J.H.S. xl. 1920, p. 137), plausible enough in itself, lacks what the present argument would if the question of style were entirely omitted. Mystic bath and raiment formed part of the ritual of many, perhaps originally of most goddesses.

16 E.g. Aus. l.c. Fig. 62 ; Boll. 1.c. Fig. 45.

17 The metaphor is common (see Hesiod, $O p$. i. 620). Compare the Orion legend, Pseudo-Eratosthenes, Catast. fr. xxxii. It is hardly necessary to remark the analogy of the general conception with such myths as those of the Theseus cycle. In the Naples group the other horseman was possibly mounting.

18 Hesiod, $O p$. i. 565, 598, 610, etc. 
pomegranate) and looks back to Persephone whom he leaves mourning or sleeping; while his brother sinks into the ocean (suggested by its denizen the fish) to the joyful or awakening Aphrodite. According to some traditions one of the Dioscuri was young and immortal, while the other was subject to the power of age and death, and each was allowed to spend one day on earth and one day in the under-world,

\section{'Si fratrem Pollux alterna morte redemit, Itque reditque viam totiens. . . .' 19}

That form of the legend would possibly prove suitable to this interpretation of the monuments, but at present the application of these details can only be tentative, as must also be any attempt to interpret the scenes as illustrating the doctrines of Pythagoras with regard to the movement and harmony of the spheres, though these are known to have spread to Locri from Croton. ${ }^{20}$ Mr. E. S. G. Robinson has shown me a Locrian bronze coin of the third century on which Persephone is seated, with a star on either side of her head; others on which the Dioscuri appear in their star-crested hats. ${ }^{21}$ On the terra-cottas from Tarentum the Dioscuri seldom appear unaccompanied by their starry paterae: the care with which these are introduced, even when not in use, makes one suspect, even if one cannot prove, some ulterior significance: I suggest an astronomical one. ${ }^{22}$ These paterae, embossed, as often there, with a single star, occur also on the Locrian terra-cottas.

The connexion between Locri and the Ludovisi and Boston reliefs extends even to resemblances in the detail of ritual, which may be fortuitous but have a certain cumulative value. We have a boy playing the lyre, and a girl playing the double flute. ${ }^{23}$ of frequent occurrence is a candelabrum or standing censer, which in some cases at least, with its conical lid, comes near to that on the Ludovisi Throne; but it is so common an instrument of ritual elsewhere that no emphasis can be laid upon it. ${ }^{24}$ Neither is there any lack of youthful winged figures such as have caused the parallel between the Boston reliefs and Attic vases to be remarked. ${ }^{25}$ It seems strange that archaeologists, in looking for the place where these two sets of reliefs were originally set up, should have passed over the claims of Locri and given preference to such places as Eryx (Lanciani and Petersen), Cyprus (Studniczka), and Kanathos (Casson), on the ground of certain religious analogies, but with little or no stylistic

19 Vergil, Aen. vi. 1. 121-2. Clement of Alexandria, Protrept. ii. 30. 5; Pind. Nem. x. fin.; $P y t h$, xi. 60 sqq. De Quincey's reference (Opium Eater, p. 78, ed. Macmillan) to the Dioscuri, as morning and evening star, going up and down like alternate buckets (possibly an imaginative re-creation of the passage of Vergil cited above) is an interesting modern parallel to the simile employed by the sculptor of the Boston relief.

20 Porphyr. Vit. Pyth. 56.

${ }^{21}$ B.M.C. Italy, p. 368, Nos. 35, 36; id. p. 369 , No. 40 .
22 Röm. Mitt. xv. 1900, p. 3 sqq. Again there is the relief in the Louvre where the Dioscuri descend to the Theoxenia as the sun with his chariot rises above them. Reinach, Reliefs, ii. p. 256, No. 4. We can hardly suppose that in all these cases the Dioscuri exercise the same functions, or that they are always identified with the same stars.

23 Aus. l.c. Fig. 82; cf. Boll. 1.c. Fig. 13.

24 Boll. 1.c. Figs. 8, 12, 16, 17; Aus. 1.c. Figs. 15, 52.

${ }^{25}$ Boll. 1.c. Figs. 12, 38; Aus. 1.c. Figg. 41,42 . 
support. Locri supplies both. Our information from various sources on its history and religion shows that it was celebrated for its works of art, and that it possessed a famous shrine of Persephone, whose cult, much favoured in Magna Graecia, had another important centre at Syracuse. The Locrian sanctuary was first desecrated by Pyrrhus, when, if we may believe the legend, most of the treasure was brought back to the shrine. ${ }^{26}$ But in 205 B.c. Scipio's legatus, Q. Pleminius, thoroughly plundered it..27 On the evidence of the terra-cottas the cult of Persephone, combined with that of other underworld deities, and possibly with that of Aphrodite, ${ }^{28}$ was celebrated with magical rites.

The hypothesis, which cannot be pressed on points of detail without further research, may be stated as follows : the Ludovisi Throne and its Boston counterpart, together with the stele from the Esquiline and possibly also the Albani relief, were all set up, though perhaps not made, at Locri. The stele from the Esquiline represents a votary of Persephone with the dove sacred to her.

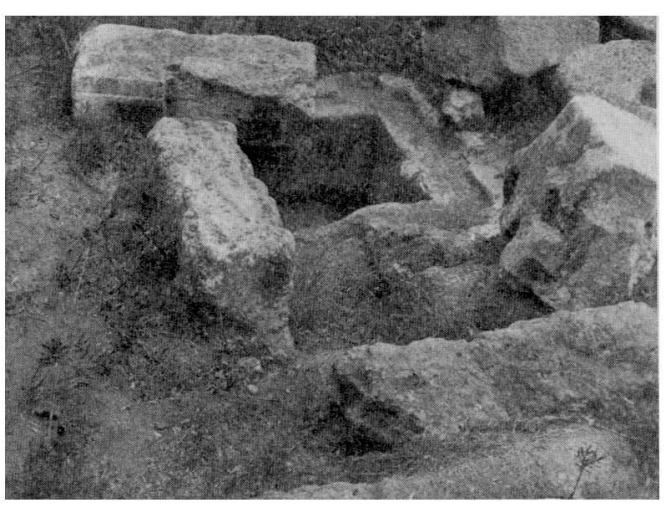

Fig. 2.-Sacred Pit at Locri.

The Albani relief shows Persephone or Demeter enthroned (with attendant worshippers on a smaller scale), holding a child, the identity of whom may be settled by further discoveries at Locri or by further study of the present material. ${ }^{29}$ Finally, the Ludovisi Throne and the Boston reliefs are the product (for which Orsi was looking) of that period of Locrian or late Ionic art analogous to the early period of Pheidias at Athens, and they represent scenes of ritual connected with an under-world goddess, probably Persephone, whose ceremonial robing was one of the principal rites. ${ }^{30}$ That the Ludovisi and Boston reliefs were carried off in Roman times is clear already from their having been found near each other in Rome itself, and history gives us the names of Roman connoisseurs whose enthusiasm may well have been responsible for their removal ${ }^{31}$; while if we are seeking for the actual spot where one or both were originally set up, there

\footnotetext{
26 Appian Samn. iii. 12; Livy xxix. 18, etc.

27 Livy xxix. 8, 16-22; Diodorus xxvii. 4, etc.

28 Aus. 1.c. Fig. 41.

29 It seems doubtful whether we are right in assuming, as Studniczka inclines to do, that the small figure who appears in the basket is Adonis, since in most cases it has long hair, and in one (Boll. l.c.
}

Fig. 41), like the child on the Albani relief, is certainly female.

so Doubtless the rites must have had a special application to the fate of the individual soul : compare Homeric Hymn to Demeter, 1. $480 \mathrm{sqq}$.

31 By certain of her officers Rome must have been filled with works of Greek art from Sicily and South Italy, few of which have been identified in modern museums. 
are few places more likely than the pit described on page 412 and illustrated on page 411 of Bollettino d'Arte l.c. (our Fig. 2), which, like the structure shown on one of the terra-cottas, ${ }^{32}$ appears to have been the centre of an important shrine. This last question complete excavation of the site alone can settle, for although the Ludovisi Throne in its internal measurements is only $.035 \mathrm{~m}$. too small, and the Boston throne $.02 \mathrm{~m}$. too large, for the two opposite sides of this pit (a discrepancy which seems less serious when we remember, not only the differing measurements of the Ludovisi and Boston thrones, but the individual irregularities of each), there are difficulties connected with the recessed frame which surrounds the pit, and with the different slope of the panels which would be adjacent to each other if both monuments were set up round it. The theory can be tested in no better way than in the light of all available evidence, notably that collected in the articles which summarise the results of excavation at Locri. Prof. Orsi's complete publication is unfortunately not to be expected for some time. To his great kindness I am indebted for permission to work on unpublished material, to visit his unfinished excavations, and to study his valuable notes.

Bernard Ashmole. 